Primljen / Received: 24.6.2016. Ispravljen / Corrected: 28.1.2017.

Prihvaćen / Accepted: 28.2.2017. Dostupno online / Available online: 10.8.2017.

\section{Regression model for predicting productivity of RC slab concreting process}

Authors:

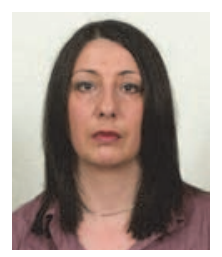

Biljana Matejević, MSc. CE

University of Nis

Faculty of Civil Engineering and Architecture biljana.matejevic@gaf.ni.ac.rs

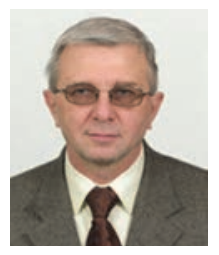

Prof.Milorad Zlatanović, PhD. CE University of Nis

Faculty of Civil Engineering and Architecture milorad.zlatanovic@gaf.ni.ac.rs
Subject review

\section{Biljana Matejević, Milorad Zlatanović}

\section{Regression model for predicting productivity of RC slab concreting process}

This paper provides a model that will ensure effective management of concreting process already at the planning stage, by predicting productivity to reduce costs and shorten the project completion time. Eighty-one RC slab concreting processes were monitored and registered on eight building construction sites. The factors that may affect productivity were identified and a multiple linear regression method was used to develop models for predicting productivity and estimating duration of the slab concreting process.

\author{
Key words: \\ model, productivity, concreting, multiple linear regression, affecting factors
}

Pregledni rad

Biljana Matejević, Milorad Zlatanović

\section{Regresijski model za procjenu produktivnosti betoniranja armiranobetonskih ploča}

U radu je dan model koji omogućuje učinkovito upravljanje procesom betoniranja, još u fazi planiranja, i to procjenom produktivnosti s ciljem smanjenja troškova i ukupnog trajanja projekta. Prikupljeni su podaci tijekom 81 betoniranja ploča na osam gradilišta na kojima se grade objekti visokogradnje. Identificirani su faktori koji mogu imati utjecaj na produktivnost, te su primjenom metode višestruke linearne regresije izrađeni modeli za procjenu produktivnosti i prognoziranje trajanja procesa betoniranja ploča.

Ključne riječi:

model, produktivnost, betoniranje, višestruka linearna regresija, faktori utjecaja

Übersichtsarbeit

Biljana Matejević, Milorad Zlatanović

Regressionsmodell für die Einschätzung der Produktivität des Betonierens von Stahlbetonplatten

Das Papier präsentiert ein Modell zu entwickeln, das eine effiziente Leitung des Betonierungsprozesses ermöglicht, und zwar noch in der Planungsphase, und dies durch Einschätzung der Produktivität mit dem Ziel der Kostensenkung und Verkürzung der gesamten Projektdauer. Während des Betonierens von 81 Platten auf acht Baustellen, auf denen Objekte des Hochbaus errichtet wurden, wurden Daten zusammengetragen. Identifiziert wurden Faktoren, die Einfluss auf die Produktivität haben können, und durch Anwendung der Methode der mehrfachen linearen Regression wurden Modelle für die Einschätzung der Produktivität und die Prognose der Dauer des Betonierungsprozesses der Platten ausgearbeitet.

Schlüsselwörter:

Modell, Produktivität, Betonieren, mehrfache lineare Regression, Einflussfaktoren 


\section{Introduction}

Numerous studies have shown that the productivity observed over the last several decades in civil engineering has not followed in most countries the growth of productivity in other branches of industry. Some of the leading economies of the world have even registered a drop of productivity in civil engineering [1]. Among the EU member countries that have available data for January 2009, civil engineering exhibits growth in three, and a decrease in eight countries [2]. The civil engineering activity in Serbia, once profitable, highly accumulative and steadily growing export activity, nowadays shares the fate of other industries in the country [3].

It is understandable that productivity has a significant and direct impact on the cost of construction of a new structure; higher productivity reduces construction costs and vice versa. In civil engineering, the work productivity is most often expressed as the production realised in a unit of time. Time and productivity are closely related: the data on productivity are used to determine duration of an activity, and so it is clear that the decline in productivity can lead to non-respect of construction deadlines. Construction is a dynamic process, and it is difficult to isolate a single factor that has a predominant impact on productivity. In the productivity analysis, many studies focus on the effects of some factors while ignoring impact of other existing factors, or their effects are determined by risk coefficients. Measuring productivity of work on a civil engineering project, as a very complex and longlasting process owing to the specifics of construction outcomes, is not sufficient in itself; it is necessary to examine and assess impact of various productivity-related factors.

For many years, concrete has undoubtedly been one of the most commonly used materials in civil engineering. The concreting process, starting from the concrete making in a concrete plant, to its transport to the construction site and placing, is a construction process applicable to a great variety of building structures. Due to the specifics of concrete as a construction material and different impacts occurring in the concreting process (interruptions, delays, irregularities, etc.), it is very important to pay special attention to the planning and realization of these works. In the framework of an overall building construction process, concreting works have a great importance from the viewpoint of quantities and costs, especially if the skeletal building system is implemented in the building construction. For such structures, concreting works represent key activities in the time schedule of the project. For this reason, it is important to perform realistic planning of such works, by good coordination of all impacts and by respecting the required productivity objectives. In our practice, the concrete process planning mostly boils down to experience, while factors impacting the productivity of the process are seldom considered. For this reason, interruptions and delays are not uncommon, or several mixers wait in queue, or the pump awaits the mixers, which generates a negative financial result.

Cooperation between the contractor and concrete plant must be conducted in such a way to ensure proper conditions for concrete placement, which is why a good planning and synchronization is necessary. However, on the one hand, the contractor must order a sufficient quantity of concrete in a timely manner so as to ensure maximum productivity on the construction site while, on the other hand, concrete plant attempts to deliver concrete for several projects simultaneously so as to increase its own productivity [4]. A proper balance between the two sides can not easily be achieved because of the nature of concrete, coordination of concrete plant performance and pump performance, limited number of mixers, varying capacities of mixers, etc. Poor management of the delivery and use of concrete could lead to expiry of concrete usability time, insufficient workload of the facility, machinery and labour, and thus to extra cost.

Although research in the area of productivity in civil engineering is not a new topic, it is always topical and important. The development of science and technology has also resulted in creation of a variety of new methods, including the Artificial Neural Networks (ANN) methods, Simulation Methods, Case Based Reasoning methods, Fuzzy Logic and others, which have all been implemented in the study of productivity [5-12]. Many scientific papers are devoted to the prediction of productivity in civil engineering, and some of them are cited in this paper [5-17]. Thomas and Zavrski [13] studied productivity of labour on a sample of: 23 projects of masonry works, 8 projects of formwork assembly works, and 11 projects of steel structure works. A theoretical basis for defining baseline productivity was developed on the basis of masonry works data, using linear regression methods. The baseline productivity is defined as the productivity realized within $10 \%$ of all workdays in which the best productivity is achieved. Such productivity tables are shown in the paper for some specific works. In case of masonry works, the baseline productivity ranges between 0,430 and $1,237 \mathrm{~h} / \mathrm{m}^{2}$, and in case of steel structures between 1,022 and $2,230 \mathrm{~h}$ /element (column or beam). The coefficient of variation (CV) is defined as a ratio of the mean error of productivity assessment to the assessed baseline productivity. The results of CV calculation: 11.5 for masonry works, 9.3 for formwork assembly works, and 10.6 for steel structure works. Certain hypotheses were made on the basis of the database established for masonry works. They were tested by means of two separate databases. The hypothesis that a more complex design actually results in the reduction of productivity was confirmed. It was also confirmed that a higher coefficient of variation indicates a higher variability of management of human resources in civil engineering. A lower coefficient of variation points to a more consistent implementation of technology and higher ability of workers [13]. Dunlop and Smith [15] analyse productivity of concreting based on the data acquired from a sample of 202 concreting activities at three construction sites of a wastewater treatment facility in Scotland. The recorded data refer to the slabs, walls and columns, and the mean productivity per element amounts to $13.6 \mathrm{~m}^{3} / \mathrm{h}$. A regression model is proposed for predicting productivity of all elements: slabs, columns, 
and walls [14]. A regression model for predicting productivity was formed in Egypt on the basis of 418 recorded concreting operations for columns, walls, slabs and beams. Concrete was transported using a crane, and the data were registered on ten construction sites. The average quantity of concrete per construction site and per each concreting was $35,24 \mathrm{~m}^{3}$, and the achieved productivity amounted to $11 \mathrm{~m}^{3} / \mathrm{h}$ [15]. In Nigeria, the workforce productivity was examined $\left(\mathrm{h} / \mathrm{m}^{3}\right)$ based on the sample of 26 concreting positions of foundation walls, columns, slabs and beams, where concrete was transported using dumper tracks. Such form of transport, although limited to foundation concreting works, is very popular in this country because of the manoeuvrability of these vehicles and unloading method, and it is implemented on $50 \%$ of construction sites. An average amount of concrete was $17,17 \mathrm{~m}^{3}$, and the achieved productivity amounted to $8,53 \mathrm{~m}^{3} / \mathrm{h}$ [16]. Anson and Wang (1998) analysed the concreting productivity in Hong Kong for various building technologies: by crane, pump, wheelbarrows and funnels. The following productivity results were obtained on the sample of 154 concreting activities for walls, columns, slabs and beams: $17,50 \mathrm{~m}^{3} / \mathrm{h}$ for concrete transport by crane, $30,40 \mathrm{~m}^{3} / \mathrm{h}$ for concrete transport by pump, and $17,30 \mathrm{~m}^{3} / \mathrm{h}$ for concrete transport by wheelbarrows [17].

The Artificial Neural Networks (ANN) method was implemented in a crane productivity study; appropriate models were formed using multiple linear regression and artificial neural networks, and a comparison was made [6]. Neural networks were implemented in Great Britain for predicting concreting productivity using ready-made concrete [7]. Other relatively new methods have also been implemented: Case Based Reasoning (CBR) [8] and Fuzzy Logic [9]. Park et al. [10] use the System Dynamics as a method for making a simulation model for predicting supply of ready-made concrete. In the paper by Labban [11], a Discrete Event Method is used to present the asphalt paving process. Zankoul and Khoury [12] investigated potential for combining the Discrete Event Method and Agent Based Simulation in the simulation of earthworks.

The main goal of this paper is to develop a model for predicting productivity of concreting operations by analysing the current state-of-the-art, by studying dominant factors, and by investigating the reasons that cause deviation from the designed parameters in the course of concreting works. A model for predicting productivity of the slab-concreting process is proposed based on the data from various construction sites on which building structures have been constructed by various contractors using services of various concrete suppliers. This goal was accomplished through production of a model for predicting the concreting process, using multiple linear regression methods.

The technology of concreting works discussed in this paper comprises concrete production in a concrete plant, transport to the construction site using concrete mixer trucks, transfer to the placing location using large truck pumps, and use of immersion vibrators for placing and compaction.

\section{Collected data}

The research on the productivity of concreting process by monitoring concrete works was conducted at various construction sites in the city of Niš. The data were collected by recording the concreting process at eight construction sites (four residential buildings, containing basement (B) + ground floor (GF) + 6 floors $(F)$, two residential buildings containing $B+G F+5 F+A t t$ (Attic), one dormitory $B+G F+11+A t t$, and one health care building $B+G F+5+A t t$. All these buildings were constructed using skeletal construction system. 141 concreting operations, involving foundation slabs, floor slabs, and beams, columns and walls, were recorded over a twenty month period. The total amount of placed concrete is 12 $799 \mathrm{~m}^{3}$ and the total time used is 648 work hours.

The process recording was performed using photo-reviewing, by entering appropriate data into the corresponding forms. The following times, events and other significant parameters were recorded and measured at the constructions sites: start of concreting, arrival of mixer truck, mixer truck positioning into the unloading position, start of unloading, washing of mixer truck funnel after unloading, mixer truck departure, waiting for the pump if there is no concrete at the construction site, mixer truck waiting in queue, various justifiable and unjustifiable interruptions (meal breaks, machinery malfunctions, adverse weather, interruptions due to organizational issues, etc.), number of workers engaged in concreting operations, number of mixer trucks in the cycle, total number of mixer trucks, intervals between arrivals of mixer trucks, quantity of placed concrete, number of pump relocations to different positions and time required for relocations, waiting of the pump for ultimate mixer truck load (addition).

The mixer truck bills of lading were used to obtain the following parameters: number of the bill, type and class of concrete, quantity of concrete per mixer truck, time of truck departure from concrete plant, distance of concrete plant from construction site. The data collected from three concrete factories (based on interviews with factory engineers) are: Concrete plant characteristics (mixer capacity, cycle duration, concreting method, mixer truck loading method, truck pump characteristics (theoretical performance, pipeline length, number of segments, hose length, potential for increasing range using extensions, number of extensions, length of extensions, reception-silo capacity, year of production).

For the purposes of this paper, a sample was singled out, which consists of slab concreting (foundation and floor slabs) in order to obtain a representative with homogenous data. This sample contains 81 concreting ( 7 foundation slabs and 74 floor structures); with the amount of placed concrete of $11.951 \mathrm{~m}^{3}$ ( $93 \%$ from the total quantity of the entire sample), and the total consumed work time is 503 hours.

To analyse the collected data and form a productivity prediction model, a statistic data processing was conducted using the MS Excel XLSTAT 2014 software add-ins. After testing the action of outliers using the Grubs' test, it was established that the sample size amounts to 78 elements. A descriptive statistics was 
Table 1. Average quantity of concrete, duration and productivity at construction sites - average value per one concreting

\begin{tabular}{|c|c|c|c|c|c|}
\hline $\begin{array}{c}\text { Construction site } \\
\text { No. }\end{array}$ & $\begin{array}{c}\text { No. } \\
\text { concreting }\end{array}$ & Floor & $\begin{array}{c}\text { Quantity of concrete per concreting } \\
{\left[\mathrm{m}^{3}\right]}\end{array}$ & $\begin{array}{c}\text { Concreting time } \\
{[\mathrm{min}]}\end{array}$ & $\begin{array}{c}\text { Productivity } \mathbf{P}_{\text {ostv }} \\
{\left[\mathrm{m}^{3} / \mathrm{h}\right]}\end{array}$ \\
\hline 1 & 10 & Temelj-VI & 102,37 & 336 & 19,59 \\
\hline 2 & 3 & V-VII & 182,67 & 608 & 18,49 \\
\hline 3 & 9 & Po-VI & 66,11 & 228 & 18,46 \\
\hline 4 & 5 & II-VI & 89,80 & 308 & 18,02 \\
\hline 5 & 8 & Po-VI & 71,13 & 216 & 21,36 \\
\hline 6 & 4 & III-Pk & 65,66 & 341 & 11,72 \\
\hline 7 & 8 & Po-Pk & 69,75 & 213 & 20,50 \\
\hline 8 & 34 & Temelj-V & 197,82 & 453 & 26,06 \\
\hline
\end{tabular}

conducted for this sample, and the mean productivity value of $21.76 \mathrm{~m}^{3} / \mathrm{h}$ was derived, with the standard deviation of $6.36 \mathrm{~m}^{3} / \mathrm{h}$. An average productivity achieved on each of the eight construction sites (obtained as a mean value of all productivities as related to the number of concreting activities on a given constructions site, not including outliers) is presented in Table 1. Average values of interruptions were calculated by measuring the time the pump waits for the arrival of concrete, and the waiting time of mixer trucks in queue to unload concrete. Based on the price the contractor must additionally pay for waiting time of the pump and/or mixer per hour (that is obtained from the concrete factories), the collected data demonstrate that the concrete pump waits for concrete 37.8 minutes or $15 \%$ of the total concreting time, which causes the waiting costs of around $1.5 € / \mathrm{m}^{3}$ of placed concrete. All mixer trucks engaged on one concreting task spend on an average 161 minutes or $62.5 \%$ of the total time waiting in line at the construction site, which causes additional cost of around $1 € / \mathrm{m}^{3}$ of placed concrete. On an average, an individual mixer waits 13 minutes to unload concrete at the construction site. In case the quantity of concrete is large, these interruption costs may be regarded as a considerable item within the total concreting costs.

\section{Impact factors}

The study of productivity comprises analysis of all impact factors, both positive and negative. Although it is clear that there is a large number of impact factors, it is important to identify and single out the most significant ones. Also, it is important to consider the factors with a negative impact on work productivity, and to eliminate and control them or find a way to divert them towards positive outcomes. The factors that have a positive effect on productivity should be emphasized and utilized. Knowing all factors that affect productivity facilitates a more accurate estimation of deadlines and project costs.

\subsection{Proposal of input parameters for regression analysis}

The original list consisted of 37 independent variables that could have an impact on the concreting process productivity. Based on a thorough study of references and extensive practical experience, and after an elimination procedure, this number of variables was reduced to 14 . The proposed variables were selected as the long-term experience on construction sites has shown that they have a significant impact on concreting process. The independent variables are classified into two groups: quantitative and qualitative, based on their characteristics and units in which they are expressed. The quantitative variables (group B1) are discrete or continuous variables that can be measured, while quantitative variables (group B2) are descriptive.

Based on collected data and experience acquired on construction sites, the following variables (dependent and independent ones) are proposed for regression analysis:

\section{A - dependent variables:}

1. Productivity of concreting process $-P\left(\mathrm{~m}^{3} / \mathrm{h}\right)$

Represents the quantity of concrete in an hour of work; it is calculated as the quotient of the total quantity of placed concrete and total time. The total required time includes pure work and all interruptions and delays.

2. Duration of concreting- $T$ (h)

Represents the time needed to place a required quantity of concrete, measured from the start to the end of concreting. The starting point of concreting is the time of unloading of the first mixer truck, and the ending point of concreting is the completion of the upper slab surface.

\section{B1 - independent quantitative variables:}

1. Quantity of concrete $-\mathrm{Q}\left(\mathrm{m}^{3}\right)$

The quantity set in the bill of quantities. In many cases the value given in the bill of quantities is not or cannot be accurate, which is why an approximate quantity is ordered and, eventually, additional quantity is ordered based on the assessment or measurement and calculation of remaining quantities. For that reason, the last mixer truck is waited for, and the duration of works is extended.

2. Number of mixer trucks in the cycle - Bmc (trucks /cycle) Since the process is cyclical in nature, the same vehicles arrive to and depart from construction site for a number of times (cycles). The number of vehicles in one cycle depends on the concrete plant performance, transport distance to construction site, and capacity of mixer trucks. An optimum 
number of vehicles must be specified, so that there is always enough concrete on construction site, and to reduce to minimum the mixer truck waiting time.

3. Average quantity of concrete per mixer truck $-\mathrm{Q}_{\mathrm{pr.m}}\left(\mathrm{m}^{3}\right)$ mixer truck)

Due to various capacities of mixer trucks, an average quantity of concrete per mixer truck is a quotient between the total quantity and total number of mixer trucks.

4. Number of workers - $\mathrm{B}_{\mathrm{r}}$ (units)

The number of workers engaged in a concreting activity. In case of concreting using pumps, the work gang normally consists of 7 to 9 workers. Two workers are needed to hold and direct the pump hose, one or two workers place the concrete using the immersion vibrator (depending on the number of immersion vibrators), two to three workers spread the concrete, and one to two workers are needed to finish the upper slab surface. In special circumstances, a larger number of workers may be required, for instance, when the range of the pump is insufficient, and the hose is supported on stands, and when scaffolds, or chutes, are used to assist in concreting operations.

5. Theoretical pump performance $-U_{t, p}\left(\mathrm{~m}^{3} / \mathrm{h}\right)$

This factor must be introduced to take into account the use of several different pumps. Theoretical performance is proposed, expressing the pump capacity.

6. Pump age - SP (years)

Represents the number of years since the time the pump was manufactured. With an increase in age of the machinery, the incidence of wear and tear of parts also increases, and the pump is therefore more susceptible to malfunction and poorer performance.

7. Pump range- DP (m)

The pump range expresses the length of the boom ( 4 or 5 sections) together with the rubber hose at the end. The extension of range is possible by adding extensions that serve at the same as hose extensions and are 4 to $5 \mathrm{~m}$ long

8. Pump relocation - PP (number)

Depending on the pump range, dimensions of the building height at which the concreting is performed, and possibility of pump access to the building, it is sometimes necessary to set the pump in several positions. The number of relocations is designated as 0 if concreting is performed from only one (initial) position of the pump, as 1 if there is one relocation of the pump (two positions) and 2 if the pump is relocated twice (there are three positions).

9. The height of concreting represents the height of the building at the moment the slab is being concreted; the heights are taken from the design $-\mathrm{V}(\mathrm{m})$

10. Slab thickness - dp (m)

Slab thickness for solid slabs is a true number while for slabs containing high beams the solid slab is an average thickness calculated based on individual proportions in surface area.

11. Distance of concrete plant from construction site $-L_{\underline{b-g}}(\mathrm{~km})$ Distance between concrete plant and construction site in kilometres.
12. Concrete plant performance- $U_{\mathrm{pr}, \mathrm{b}}\left(\mathrm{m}^{3} / \mathrm{h}\right)$

Practical performance of concrete plants is calculated based on cycle duration and mixer truck capacity.

\section{B2 - independent quality variables:}

\section{Slab type-TP}

In the observed sample, there are solid RC slabs, RC slabs with beams, and lattice-concrete joists. They are divided into two groups: slabs marked with TP-P only, and slabl with beams and lattice-concrete joists marked as TP-PG.

14. Availability of concrete plant - RasB

Delay $n$ concrete delivery may be experienced if a concrete plant delivers concrete for several construction sites simultaneously, or for its own production (prefabricated structural elements, for instance). According to the sequence of bills of lading, it can be concluded whether the concrete plant supplies concrete to the considered construction site only -marked with 0 , or if it supplies concrete to other construction sites as well - marked with 1.

\section{Regression analysis}

The relations among the phenomena can be deterministic (functional, exact) and stochastic (statistical). While in deterministic relations the output is precisely defined with the function of input data (one value of the independent variable corresponds to only one precisely defined value of the dependent variable), in stochastic relations there is a certain randomness (one value of the independent variable corresponds to a number of possible values of the dependent variable). In practice, the number of phenomena governed by stochastic relations is much greater. One of the methods that can be implemented for the stochastic-process data analysis is multiple regression. This method is suitable in the cases when the problem involves one dependent or several independent variables. If the relation between the data is linear, the case boils down to a multiple linear model. The base form of multiple linear regression model is given by the equation (1):

$Y=b_{0}+b_{1} X_{1}+b_{2} X_{2}+\ldots b_{p} X_{p}+e_{i}$

where:

$\mathrm{Y}$ - dependent variable

$\varepsilon_{i}$ - random error

$X_{1}, X_{2}, \ldots, X_{p}$ - dependent variables

$b_{0}, b_{1}, \ldots, b_{p}$ - regression coefficients.

The goal of regression analysis is to identify the mode of relation (dependence) between the observed phenomena, which is accomplished by production of an appropriate regression model [18]. After production of the model, its quality and representativeness in describing dependence between the considered phenomena must be assessed. The Analysis of Variance - ANOVA is used for this purpose. As a powerful tool for analysing quality of the model, the ANOVA 
calculates representativeness parameters such as: coefficient of correlation (multiple R), coefficient of determination - $R^{2}(R$ Square), standard regression deviation (Standard Error), F-test (F ratio).

\section{Production of regression model}

Since the productivity and time are inversely proportional, if one variable is known, it is possible to simply calculate the other one. This paper proposes production of a regression model that will serve for predicting productivity, and as a basis for simple calculation of the duration of works. It also enables direct prediction of the concreting process duration. The comparative analysis of both models will indicate the advantages and disadvantages of either of them, and point to implementation of the better one.

It is assumed that there is a linear relation between the variables: both between all the independent variables and between the independent and dependent ones. One of prerequisites for the use of regression analysis is the existence of linear dependence between the variables. It is necessary because the analysis starts by calculating simple correlation coefficients (bivariate correlations) for all variable pairs, and all the calculations require linear relation between the variable pairs. The number of data in the sample is $\mathrm{N}=78$ and the number of independent variables initially taken into consideration is 14 , and so the condition of the required number of data has been fulfilled. The number of data in the condition must be no less than three times higher than the number of variables (or else, the regression coefficients would be unreliable) [19]. The correlation analysis is presented below, and regression models are made for predicting productivity (model P) and duration of concreting (model T) with the same input variables.

\subsection{Model for predicting productivity of concreting process}

Backward method was implemented for development of the productivity prediction model. This method comprises simultaneous introduction of all variables into regression analysis in the first step, and gradual elimination of the variables that do not meet certain requirements, for as long as it is possible to improve the model. There are several criteria for testing compliance with the requirements. The one implemented in this paper is the so called t-test. If the absolute value of parameter $t$ (statistics of the Student's t-distribution) is lower than the critical value $t_{k r}$ which can be obtained from appropriate tables, and if the value $P_{r}>0.05$ for the reliability interval of $95 \%$ as it is assumed here, the variable is eliminated from further analysis.

Table 2. Variance inflation factor - VIF

\begin{tabular}{|c|c|c|c|c|c|c|c|c|c|c|c|c|c|c|c|}
\hline Stataistic & $\mathbf{Q}$ & $d p$ & V & $\mathrm{Br}$ & Bmc & Qpr,m & Ut,p & SP & DP & PP & Upr,b & Lb-g & RasB & TP-P & TP-PG \\
\hline Tolerance & 0,31 & 0,430 & 0,467 & 0,878 & 0,694 & 0,675 & 0,122 & 0,438 & 0,160 & 0,619 & 0,413 & 0,482 & 0,867 & 0,608 & 0,608 \\
\hline VIF & 3,112 & 2,326 & 2,139 & 1,138 & 1,442 & 1,482 & 8,205 & 2,285 & 6,265 & 1,615 & 2,423 & 2,074 & 1,154 & 1,644 & 1,644 \\
\hline
\end{tabular}

Table 3. Parameters of model P (first step)

\begin{tabular}{|c|c|c|c|c|c|c|}
\hline Source & Value & Standard error & $\mathbf{t}$ & $\operatorname{Pr}>|t|$ & Lower bound (95\%) & Upper bound (95\%) \\
\hline Intercept & 21,684 & 6,643 & 3,264 & 0,002 & 8,421 & 34,946 \\
\hline Q & 0,026 & 0,005 & 4,840 & $<0,0001$ & 0,015 & 0,036 \\
\hline $\mathrm{dp}$ & $-19,106$ & 3,084 & $-6,195$ & $<0,0001$ & $-25,264$ & $-12,949$ \\
\hline V & $-0,122$ & 0,041 & $-2,983$ & 0,004 & $-0,203$ & $-0,040$ \\
\hline $\mathrm{Br}$ & 0,000 & 0,000 & & & & \\
\hline $\mathrm{Bmc}$ & 1,404 & 0,337 & 4,172 & $<0,0001$ & 0,732 & 2,076 \\
\hline Qpr,m & 1,763 & 0,583 & 3,026 & 0,004 & 0,600 & 2,926 \\
\hline Ut,p & $-0,038$ & 0,022 & $-1,704$ & 0,093 & $-0,082$ & 0,006 \\
\hline $\mathrm{SP}$ & $-0,719$ & 0,152 & $-4,727$ & $<0,0001$ & $-1,023$ & $-0,415$ \\
\hline $\mathrm{DP}$ & 0,000 & 0,000 & & & & \\
\hline $\mathrm{PP}$ & $-3,071$ & 0,621 & $-4,942$ & $<0,0001$ & $-4,311$ & $-1,830$ \\
\hline Upr,b & 0,000 & 0,000 & & & & \\
\hline Lb-g & $-0,422$ & 0,051 & $-8,340$ & $<0,0001$ & $-0,524$ & $-0,321$ \\
\hline RasB & $-4,511$ & 0,707 & $-6,376$ & $<0,0001$ & $-5,923$ & $-3,098$ \\
\hline TP-P & 4,854 & 0,736 & 6,591 & $<0,0001$ & 3,384 & 6,324 \\
\hline TP-PG & 0,000 & 0,000 & & & & \\
\hline
\end{tabular}


Table 4. Model P parameters (final model)

\begin{tabular}{|c|c|c|c|c|c|c|}
\hline Source & Value & Standard error & $\mathbf{t}$ & $\operatorname{Pr}>|t|$ & Lower bound (95\%) & Upper bound ( $95 \%$ ) \\
\hline Intercept & 14,533 & 5,233 & 2,783 & 0,007 & 4,109 & 24,957 \\
\hline $\mathrm{dp}$ & $-17,307$ & 2,939 & $-5,890$ & $<0,0001$ & $-23,172$ & $-11,441$ \\
\hline V & $-0,118$ & 0,041 & $-2,855$ & 0,006 & $-0,201$ & $-0,036$ \\
\hline $\mathrm{Bmc}$ & 1,255 & 0,330 & 3,808 & 0,000 & 0,597 & 1,913 \\
\hline Qpr,m & 1,764 & 0,591 & 2,985 & 0,004 & 0,584 & 2,943 \\
\hline SP & $-0,548$ & 0,116 & $-4,729$ & $<0,0001$ & $-0,779$ & $-0,317$ \\
\hline PP & $-2,998$ & 0,629 & $-4,769$ & $<0,0001$ & $-4,253$ & $-1,743$ \\
\hline Lb-g & $-0,432$ & 0,051 & $-8,451$ & $<0,0001$ & $-0,534$ & $-0,330$ \\
\hline RasB & $-4,453$ & 0,717 & $-6,213$ & $<0,0001$ & $-5,883$ & $-3,022$ \\
\hline Q & 0,026 & 0,005 & 4,957 & $<0,0001$ & 0,016 & 0,037 \\
\hline TP-P & 4,675 & 0,739 & 6,324 & $<0,0001$ & 3,199 & 6,150 \\
\hline
\end{tabular}

After analysis of variance (ANOVA), it can be observed according to the variance inflation factor (VIF) that the multi-collinearity problem does not exist (Table 2). If VIF $>10$ the multi-collinearity problem is present [19]. Since, according to the table, the VIF of all variables is lower than 10, the analysis continued. After the first step, the backward regression provided parameters for the productivity prediction model (Table 3). Based on the $P_{r}$ value and $t$ parameter, it can be concluded that individual variables are not statistically important (if $P_{r}>0,05$ or $|t|<t_{k r}$ ) and that they should be eliminated from further consideration. For the sample size of $N=78$, the number of variables $p=14$, and number of degrees of freedom $D F=N-p-1=63$, from the Student's t-distribution tables, $\mathrm{t}_{\mathrm{kr}}=2,00$ [20].

The variables that are not statistically significant are highlighted in Table 3. These variables are: number of workers, pump range, concrete plant practical performance and slab TP- PG. The importance of the theoretical pump performance is insufficient since $I t I=1,704<t_{k r}$

It is assumed that number of workers variable has no impact, because the working gang was always formed with an appropriate, sufficient number of workers for the process, i.e. there were no interruptions and productivity decrease for these reasons. The pump range variable was not statistically important because the insufficient range was solved by adequate dislocation of the pump, or by building extensions using rubber hoses and flumes, which had no impact on productivity. Also, practical performance of concrete plant and slab type with beams did not have any impact on the change in productivity.

After elimination of the mentioned variables, the second step of the analysis was conducted and the final form of the regression model for predicting productivity of the slab concreting process was obtained. Regression coefficients are provided in Table 4 (all variables are statistically important: $P_{r}<0.05$ ), while mathematical form of the model is shown in Formula (2).

The final model has ten independent variables and it amounts to:

$$
\begin{aligned}
P_{p r o g} & =14,533-17,307 d p-0,118 \mathrm{~V}+1,255 B_{m c}+1,764 Q_{p r . m} \\
& -0,548 S P-2,998 P P-0,132 L_{b-g}-4,453 R a S B+0,026 Q \\
& +4,675 T P-P\left[\mathrm{~m}^{3} / \mathrm{h}\right]
\end{aligned}
$$

where $P_{\text {prog }}$ means predicted productivity $\left(\mathrm{m}^{3} / \mathrm{h}\right)$.

The variables with positive regression coefficients have an impact on the increase in productivity. These variables are: number of mixers per cycle, average quantity of concrete per mixer, quantity of concrete and slab type-P. A greater number of mixers in the cycle ensures better supply of construction site with concrete (there is no pump waiting time, or it is shorter), and so a greater quantity of concrete can be placed. Also, greater quantities of concrete per mixer result in a smaller loss of time required to position the mixer into an unloading position, and to wash the funnel after unloading. Placing of concrete to form slabs of equal thickness (slab type -P) requires less time than in case of slabs with ribs and beams, where cross sections are more complex and difficult to access, and so the productivity is higher. These are the expected results. Nevertheless, it was observed that an increase in the quantity of concrete placed also results in an increase in productivity, i.e. each $10 \mathrm{~m}^{3}$ of concrete increases productivity by $0.26 \mathrm{~m}^{3} / \mathrm{h}$.

Other variables have a negative impact, i.e. they reduce productivity. It is understandable that the productivity decreases with an increase in height at which concrete is placed, and that pump age, its relocation, and the fact that concrete plant simultaneously serves other construction sites as well, leads to interruptions and hence results in lower productivity.

Based on the obtained model (2), it can be concluded that the following variables have a higher impact on the change of productivity: slab thickness, pump relocation, availability of concrete plant and slab type. If all other variables are kept constant, and the slab thickness is increased by $10 \mathrm{~cm}$, the productivity will decrease by $1,73 \mathrm{~m}^{3} / \mathrm{h}$. This is not an expected impact because concrete placing into elements with a higher quantity of concrete per unit of measurement $-\mathrm{m}^{3}$, should be shorter, and thus lead to higher productivity. However, this could be due to the fact that the high-thickness slabs (thicker than 20 
$\mathrm{cm}$ ) were not concreted in $15 \mathrm{~cm}$ thick layers, as stipulated in standards, so that the filling and vibrating time was longer. Every relocation of the pump reduces the productivity by approximately $3 \mathrm{~m}^{3} / \mathrm{h}$, i.e. if a solid RC slab without ribs or beams is concreted, the productivity increases by about $4.7 \mathrm{~m}^{3} / \mathrm{h}$, and if the concrete plant simultaneously supplies other construction sites, the productivity decreases by about $4,5 \mathrm{~m}^{3} / \mathrm{h}$, etc.

The quality of this model can be verified via the coefficient of determination $\mathrm{R}^{2}$ which amounts to 0,857 (Table 5). This means that $85.7 \%$ of variability of the dependent variable $P$ is explained with the proposed ten independent variables. A high value of this coefficient points to a good quality of the model. A higher coefficient of determination means a higher capacity of the model to explain the regression function and to predict the dependent variable with greater accuracy. In the same table, the value of the Durbin-Watson statistic, $D W=1,733$ confirms that the requirement of non-existing autocorrelation has been fulfilled. The DW statistic value ranges between 0 and 4, with 2 as the median value. If the value is around 2 or lower, there is no linear connection between any two terms $\varepsilon_{\mathrm{i}}$ and $\varepsilon_{\mathrm{j}}$ [19].

Table 5. Evaluation of model $P$ quality

\begin{tabular}{|c|c|}
\hline Observations & 78,000 \\
\hline Sum of weights & 78,000 \\
\hline DF & 67,000 \\
\hline R $^{2}$ & 0,857 \\
\hline Adjusted $\mathrm{R}^{2}$ & 0,836 \\
\hline MSE & 6,706 \\
\hline RMSE & 2,590 \\
\hline DW & 1,733 \\
\hline
\end{tabular}

In order to justify the use of regression equation for prediction, it should be determined whether the explaining variables are important for behaviour of the dependent variable. The F-test is used in this testing: if $\mathrm{F}>\mathrm{F}_{\mathrm{kr}}$ the coefficients are different from the basic hypothesis, which is renounced and an alternative hypothesis is accepted. From the table for F-test, at the confidence level of $99 \%, F_{k r(0,01)}=2,35$ [20]. In addition, since $F=40,313$ (Table 6) is higher than $\mathrm{F}_{\mathrm{kr}}$ it can be concluded that the implementation of the proposed productivity prediction model is justified.

The agreement of the achieved productivity values and the values predicted based on the proposed model is shown in diagram presented in Figure 1. The dispersion diagram shows that most of the points are situated around the straight line 1:1 (fitted line) within the confidence interval of $95 \%$. It can be observed that only three points are outside the range, or in border areas, which amounts to only $3,8 \%$ of the total number of points.

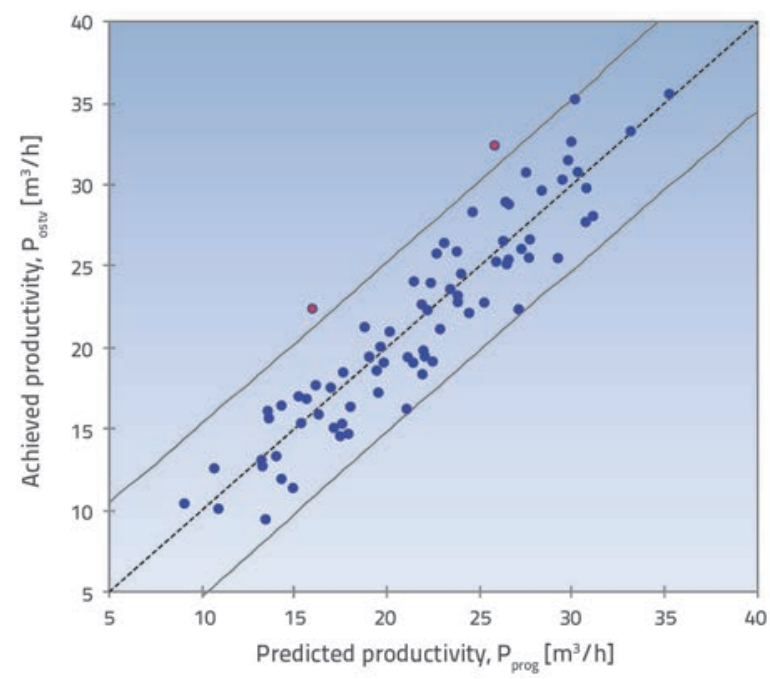

Figure 1. Agreement of achieved and predicted concreting process productivity values

If it is assumed that the variance is constant is true, then residuals have a normal distribution. For the formed model, the standardized residuals of predicted productivity form a random distribution, which is confirmed by the diagram in Figure 2 .

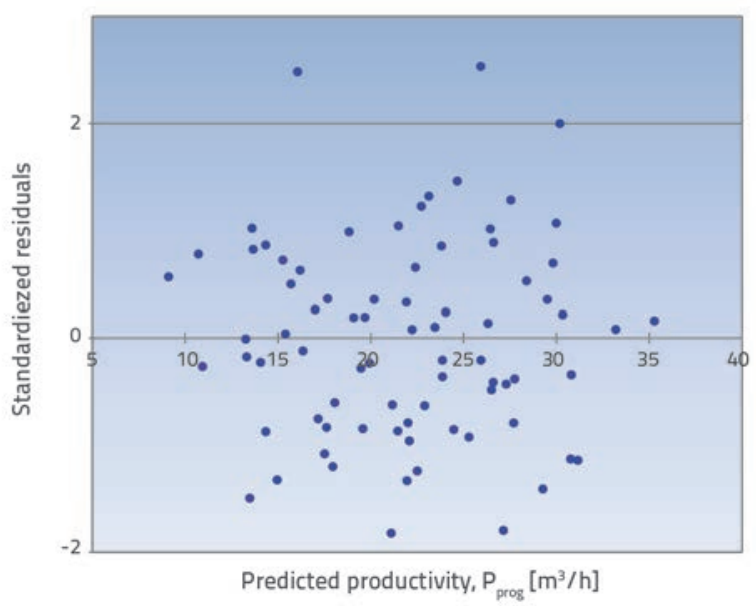

Figure 2. Standardized residuals of model P

\subsection{Model for predicting duration of concreting process}

The analysis was conducted in the same way as for the model for predicting productivity (model P), and a new model was

Table 6. Evaluation of model P significance

\begin{tabular}{|c|c|c|c|c|c|}
\hline Source & DF & Sum of squares & Mean squares & F & Pr $>$ F \\
\hline Model & 10 & 2703,562 & 270,356 & 40,313 & $<0,0001$ \\
\hline Error & 67 & 449,333 & 6,706 & & \\
\hline Corrected Total & 77 & 3152,896 & & & \\
\hline
\end{tabular}


created for predicting duration of the concreting process (model T). After three steps, the backward regression yielded a model shown in expression (3).

$$
\begin{aligned}
T_{\text {prog }} & =-0,301+6,02 d p+0,029 \mathrm{~V}-0,013 B_{m c} \\
& +0,153 S P+0,888 P P-0,021 U_{p r, b}+0,068 L_{b-g}+1,322 R a s B(3) \\
& +0,032 Q-1,145 T P-P[\mathrm{~h}]
\end{aligned}
$$

where $T_{\text {prog }}$ means the predicted time of concreting (h).

The coefficient of determination $\mathrm{R}^{2}$ amounts to 0.943 which means that $94.3 \%$ of variability of the dependent variable $T$ is explained with the proposed ten independent variables. The F-test statistics $(F=111.266)$ indicates that the use of the proposed model in the prediction of concreting duration is justified. Figure 3 shows agreement of the achieved and predicted concreting duration values based on the proposed model.

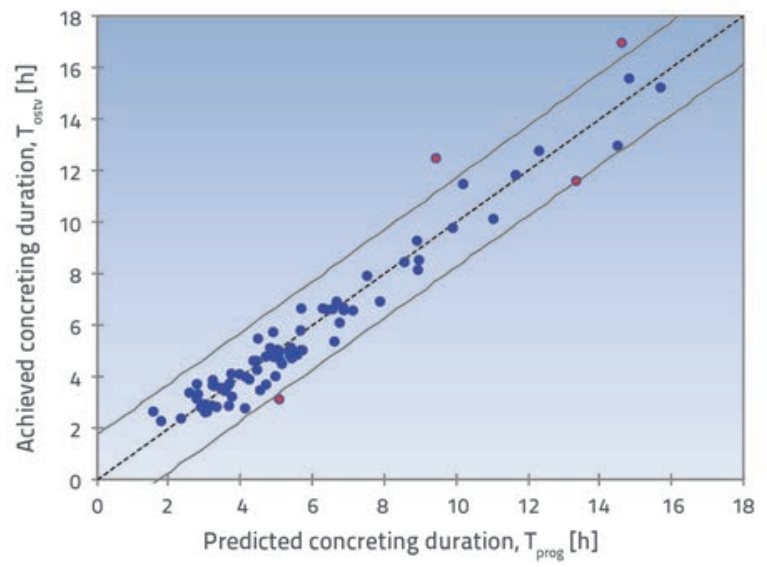

Figure 3. Agreement of achieved and predicted concreting duration values

\section{Discussion of proposed models}

The proposed models have the same number of statistically important independent variables, and exhibit an almost identical combination of such variables. The difference only concerns variables: average quantity of concrete per mixer occurs in productivity prediction models but is not present in the concreting-duration prediction models. The variable of practical performance of concrete plant occurs in model $T$, but is not included in model P. The values of determination coefficients $\mathrm{R}^{2}$ are quite high, which confirms the quality of the model. In this respect, the value of this coefficient is slightly higher for model $T$, as can be observed in diagram presented in Figure 3. Thus it can be argued that this model has a better power of prediction compared to the previous one. Namely, the points on this dispersion diagram are considerably more narrowly distributed along the regression line. As to the F-test statistics, the value $F$ is larger in case of the model T compared to the model P. Both models were also evaluated on the basis of the mean absolute error between the achieved and predicted values of MAPE (Mean Absolute Percentage Error).
The values of MAPE $=9,69 \%$ and MAPE $=11,20 \%$ were obtained for model $P$ and model $T$, respectively. Even though the determination coefficient for model $T$ is higher, the higher percentage of mean absolute error has been registered. Figure 4 shows a comparison of achieved productivities (blue) and predicted productivities (orange) and, similarly, Figure 5 shows a comparison of achieved and predicted concreting durations.

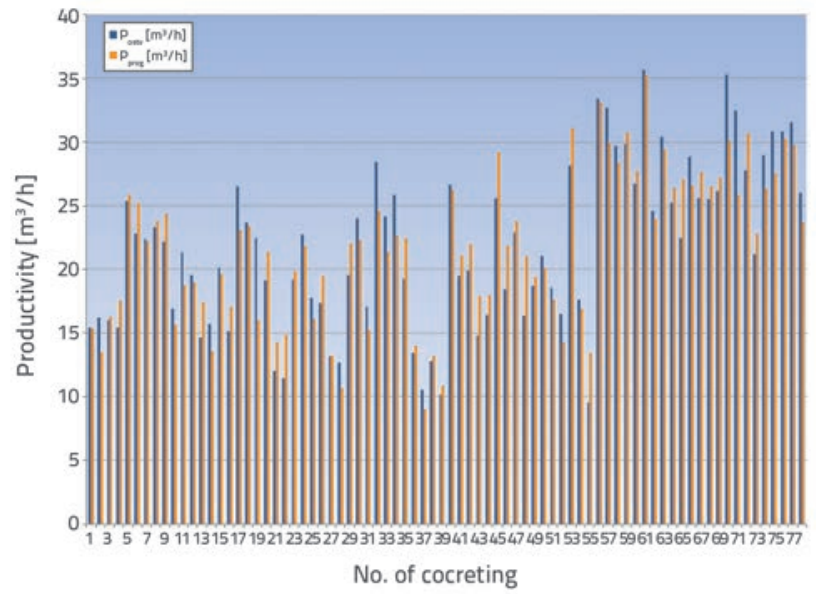

Figure 4. Achieved and predicted concreting process productivity values

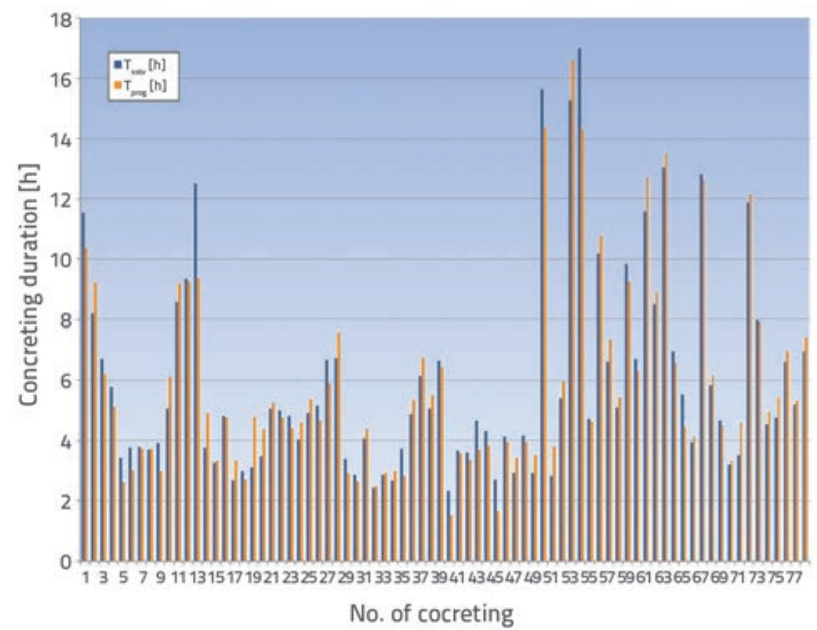

Figure 5. Achieved and predicted concreting process duration values

To enable further analysis of the models, the results were sorted (Figure 6) based on the absolute percentage error (APE) and according to productivity. The recorded concreting processes were divided into seven groups according to productivity, as follows: up to $10,10-15 ; 15-20 ; 20-25 ; 25-30 ; 30-35$, and in excess of $35 \mathrm{~m}^{3} / \mathrm{h}$. Absolute errors were divided into four groups: up to $10 ; 10-25 ; 25-50$ and in excess of $50 \%$.

It was established that $62 \%$ of the results have an absolute productivity prediction error of less than $10 \%$, i.e. $95 \%$ of all results were predicted with an error of up to $25 \%$. Higher deviations occurred in only $5 \%$ of the results, with an error of up to $50 \%$. There were no errors higher than $50 \%$ between the achieved and predicted productivity results. On this basis, it 
can be concluded that model $\mathrm{P}$ is better suited for predicting productivities having values higher than $20 \mathrm{~m}^{3} / \mathrm{h}$, since there the APE is mostly situated within $10 \%$.

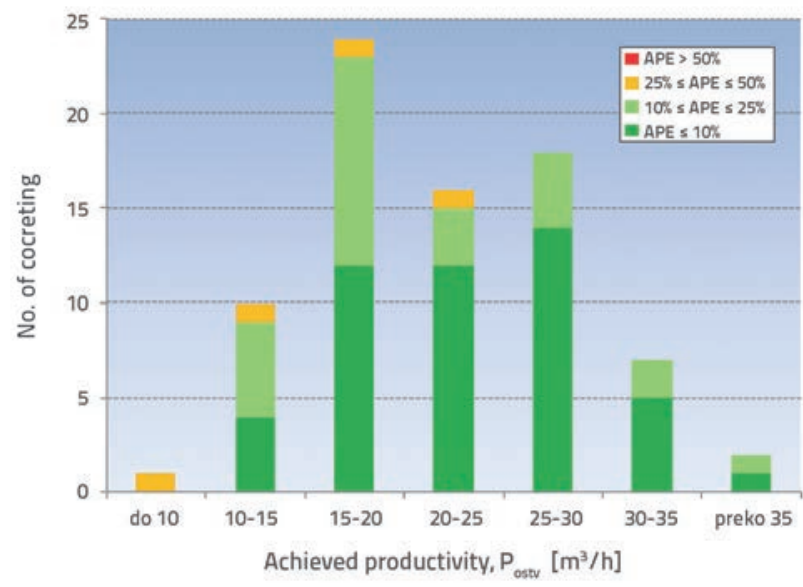

Figure 6. Histogram of productivity achieved according to APE

Sorting of results (Figure 7) was performed for the T as well on the basis of the absolute percentage error (APE) and classification of concreting according to duration. Thus, the recorded concreting processes were classified into four groups according to duration: up to $4 \mathrm{~h} ; 4-8 \mathrm{~h} ; 8-12 \mathrm{~h}$, and in excess of $12 \mathrm{~h}$. Absolute percentage errors were classified into four groups: up to $10 \% ; 10-25 \% ; 25-50 \%$, and in excess of $50 \%$.

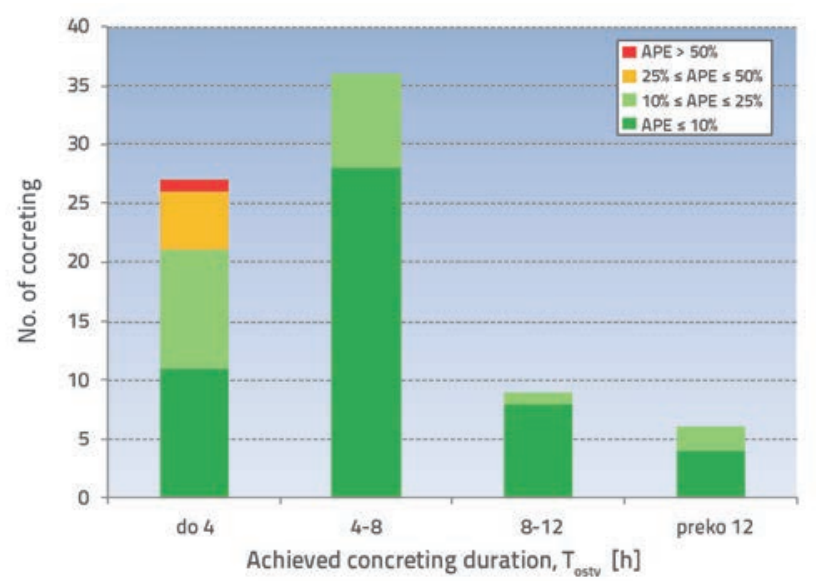

Figure 7. Histogram of duration according to APE

Based on the model T classification, it can be concluded that 93 $\%$ of results were predicted with an error of up to $25 \%$ (65\% with an error of up to $10 \%$, and $27 \%$ with an error of $10-25 \%$ ). Only 6 $\%$ of the results had an error of more than $25 \%$, and 1 result had an error of $53 \%$. The model T yields better results for concreting lasting in excess of 4 hours. All the errors over $25 \%$ occurred in the cases when concreting lasted less than 4 hours.

The model quality analysis was performed in relation to the quantity of concrete. For that purpose, the percentage error (PE) was calculated so as to easier assess the quantity of concrete for which productivity (duration) was overestimated or underestimated. The percentage deviation of achieved and predicted productivities, or duration of concreting classified in an ascending order in terms of quantities of concrete, is presented in Figures 8 and 9.

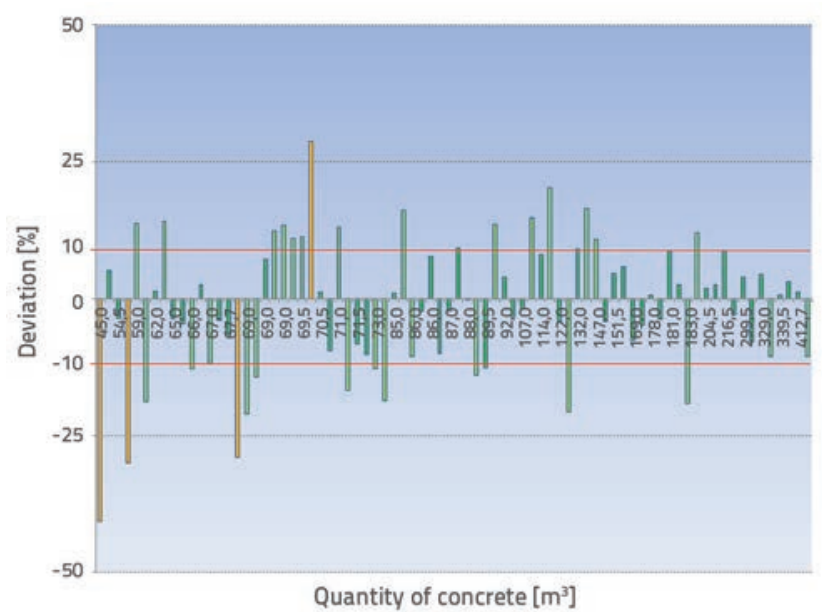

Figure 8. Percentage error in model $P$

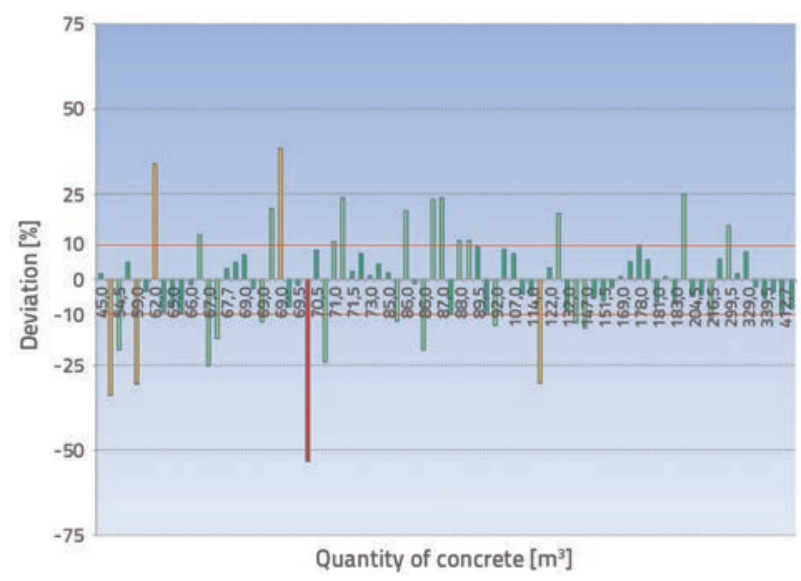

Figure 9. Percentage error in model T

The cases where higher actual productivity deviations occurred compared to predicted deviations (yellow colour in the diagram) were mostly due to some interruptions that were not taken into consideration when the model was formed. For instance, concreting was slower due to unfinished formwork or reinforcement, or due to poor batch of concrete that had to be returned to the concrete plant. In such cases, the predicted productivity is naturally higher than the achieved one. PE values shown in the diagram are negative (Figure 8 ). The productivity with the positive PE value of $+28,79 \%$ occurred in the case when concreting was performed during snowfall. Since weather conditions were not taken into consideration during regression analysis here, obviously, the impact of snow had a positive effect on productivity: the work was faster as efforts were made to complete the work sooner than under usual circumstances. In addition, Figure 8 also shows that small deviations between the achieved and predicted productivities occurred in case of larger quantities of concrete, especially for quantities in excess of 100 $\mathrm{m}^{3}$. 
When duration prediction is concerned, as opposed to the productivity prediction, the cases with a higher error are those in which predicted duration is higher compared to the achieved one, which is mainly due to better organization and absence of unnecessary interruptions, and so the concreting was completed within a shorter period of time. In these cases, i.e. when predicted duration is higher than the achieved one, $P E$ values shown in the diagram are negative (Figure 9). The highest deviation, $\mathrm{PE}=-53,04 \%$ occurred for the same case of concreting during snowfall.

As in the case of productivity prediction, the duration prediction (Figure 9) registers smaller deviations between the achieved and predicted values in case of larger quantities of concrete, especially those in excess of $100 \mathrm{~m}^{3}$. This model is also better in predicting duration for larger quantities of concrete, in excess of $100 \mathrm{~m}^{3}$.

It was established that productivity of the concreting process is higher for larger quantities of concrete, in excess of $200 \mathrm{~m}^{3}$. This phenomenon can be explained by the fact that the work is taken more seriously in case of larger concreting operations, since they take a longer time to finish. In addition, the concrete plant makes concrete for the designated construction site only, and so the time spent in waiting for the concrete is shorter. Because the work is expected to last longer, the actual work is faster, without interruptions, as the effort is made to finish the work sooner, which increases the productivity. Also, higher productivity can be achieved due to the fact that some smaller individual delays and other disruptions can be compensated for during the protracted working process.

The models proposed for predicting productivity of the concreting process (model P) and concreting duration productivity (model T) can be a useful tool in the work planning phase. These models allow a more accurate prediction of activity duration during concreting works, which enables a more efficient management and guidance of the concreting process.

\section{Conclusion}

Regression models proposed for predicting productivity and duration of reinforced concrete slab pump-based concreting process, are presented and discussed in the paper. Two models were formed using multiple linear regression: model
$\mathrm{P}$, for predicting slab concreting productivity and model $\mathrm{T}$, for predicting slab concreting duration. Both models were found satisfactory, based on criteria investigated to analyse their quality. It can be said that model $T$ has a mild advantage for implementation because, due to a slightly higher determination coefficient, $\mathrm{R}^{2}$ and $\mathrm{F}$ statistics, it is considered to be more representative. However, model $P$ appears to have an edge with regard to the mean absolute error (MAPE). Both models have a very similar combination of important variables, and an identical number of such variables. Model $P$ exhibits a better prediction capability for productivities higher than $20 \mathrm{~m}^{3} / \mathrm{h}$, i.e. while model $\mathrm{T}$ is favoured for durations in excess of 4 hours. As to the quantity of concrete, model $P$ exhibits a better prediction power (smaller deviations) when the quantities exceed $100 \mathrm{~m}^{3}$ but, in case of higher quantities, the predicted values are mostly underestimated. With regard to the quantity of concrete, model T also provides better results for quantities in excess of $100 \mathrm{~m}^{3}$, while for higher quantities it mostly predicts longer durations than the achieved ones. This can be explained by the fact that a bigger quantity requires a longer time, and so the organization of the process is better, and there are less interruptions and unnecessary losses.

The proposed models can be useful in the planning phase, as they enable a more accurate prediction of activity duration when performing concreting works. By predicting productivity and duration of concreting, one can improve the decision making, the work flow, and the concreting process management, all aimed at increasing productivity, shortening concreting time, and reducing costs.

The recommendations for further research can involve a sample increase by including a greater number of construction sites, and the existing database expansion by measuring at construction sites in multiple cities, as some characteristics of the contractors and concrete makers registered in a certain area can have a certain effect on the results. Simultaneously, process recording both in the concrete plant and at construction site would allow a more realistic analysis of the entire process. Inclusion of new variables, their analysis, and testing of their impact, could also contribute to the production of a model that can predict productivity with a greater accuracy. Also, the research can be expanded to other concreting technologies, such as, transport of concrete by crane.

\section{REFERENCES}

[1] Abdel-Wahab M., Vogl, B.: Trends of productivity growth in the construction industry across Europe, US and Japan, Construction Management and Economics, 29 (2011) 6, pp. 635-644.

[2] Makroekonomija Srbije, www.makroekonomija.org

[3] Privredna komora Srbije, www.pks.rs/PrivredaSrbije.aspx?id=7

[4] Asbach, L., Dorndorf, U., Pesch, E.: Analysis, modeling and solution of the concrete delivery problem, European Journal of Operational Research, 193 (2009) 3, pp. 820-835.
[5] Panas, A., Pantouvakis, J.P.: Evaluating Research Methodology in Construction Productivity Studies, The Built \& Human Environment Review, 3 (2010) 1, pp. 63-85.

[6] Leung, A., Tam, C.M., Liu, D.K.: Comparative study of artifcial neural networks and multiple regression analysis for predicting hoisting times of tower cranes, Building and Environment, 36 (2001) 4, pp. 457-467. 
[7] Graham, L.D., Forbes, R.D., Smith, D.S.: Modeling the ready mixed concrete delivery system with neural networks, Automation in Construction, 15 (2006) 5, pp. 656-663.

[8] Graham, D., Smith, S.D.: Estimating the productivity of cyclic construction operations using case-based reasoning, Advanced Engineering Informatics, 18 (2004) 1, pp. 17-28.

[9] Hanna, A.S., Taylor, C.S., Sullivan, K.T.: Impact of extended overtime on construction labor productivity, Journal of Construction Engineering and Management, 131 (2005) 6, pp. 734-739.

[10] Park, M., Kim, W.Y., Lee, H.S., Han, S.: Supply chain management model for ready mixed concrete, Automationh in Construction, 20 (2011) 1, pp. 44-55.

[11] Labban, R., AbouRizk, S., Haddad, Z., Elsersy, A.: A discrete event simulation model of asphalt paving operations, Proceedings of the 2013 Winter Simulation Conference, (2013), pp. 3215-3223, https://doi.org/10.1109/WSC.2013.6721687

[12] Zankoul, E., Khoury, H.: Evaluation of Agent-Based and DiscreteEvent Simulation for Modeling Construction Earthmoving Operations, Conference paper, June 2015

[13] Thomas, H.R, Zavrski, I: Construction baseline productivity: Theory and practice, Journal of Construction Engineering and Management, 125 (1999) 5, pp. 295-303.
[14] Dunlop, P., Smith, S.D.: Estimating key characteristics of the concrete delivery and placement process using linear regression analysis, Civil Engineering and Environmental Systems, 20 (2003) 4, pp. 273-290.

[15] Abd-El, H.: Predicting the Production Rate og Pouring Ready Mixed Concrete Using Regression Analysis, Journal of Civil Engineering and Science, 3 (2014) 4, pp. 219-234.

[16] Olaoluwa, O., Adesanya, D.A.: Productivity of Concrete Placement by Dumpers in Nigeria, International Journal of Engineering Research and development, 11 (2015) 3, pp. 15-28.

[17] Anson, M., Wang, S.Q.: Performance of concrete placing in Hong Kong buildings, Journal of Construction Engineering and Management, 124 (1998) 2, pp.116-124.

[18] Popović, B., Blagojević, B.: Matematička statistika sa primenama u hidrotehnici, drugo izdanje, Izdavačka jedinica Univerziteta u Nišu, 1999.

[19] Mendenhall, W., Sincich, T.: A Second Course in Statistics Regression Analysis, Seventh edition, Pearson, 2011.

[20] Statističke tablice, www.pfos.hr 